\title{
画像処理援用き裂進展試験システムの開発と
}

\author{
中高温下 $K$ 值制御疲労試験への応用 ${ }^{\dagger}$

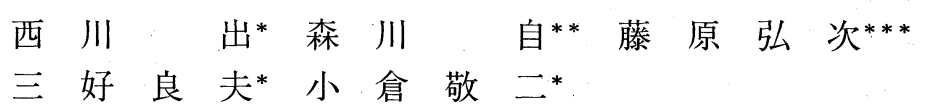

\section{A New Crack Growth Test System and Its Application to $K$-Controlled Fatigue Crack Growth Tests at Elevated Temperatures}

by

\author{
Izuru Nishikawa*, Hajime Morikawa**, Hirotsugu Fujiwara*** \\ Yoshio Miyoshi* and Keiji OGURA*
}

\begin{abstract}
A new automated crack growth test system with the aid of an image processing technique was developed. This system consists of a mechanical stage with a CCD camera, an image processing unit and a personal computer. A CCD camera with an image guide scope was used to monitor the microscopic image of a crack tip. This image around the crack tip was processed and analyzed by using a template -scanning technique to make a real-time recognition of the crack tip. The crack length was determined from the detected crack tip location. The crack growth rate and stress intensity factor were also calculated and recorded on a magnetic medium. This system was widely applicable to various fracture mechanics tests with no limitations in sample shape, environment and so on. Several $K$-controlled fatigue crack growth tests both at room and elevated temperatures were conducted to demonstrate the reliability, performance and precision of this system.
\end{abstract}

Key words : Image processing, Template scanning, Crack tip recognition, Stress intensity factor, Fatigue crack growth, Elevated temperature, Threshold

\section{1 緒論}

原子炉・高速増殖炉などの高温環境下で使用される 金属材料の予寿命評価の手法確立の重要性が強く認識 されつつあるが, これらの基礎となる破壊力学実験に はき裂長さの計測が不可欠である。この計測はこれま で移動顕微鏡などの光学系を用いて目視により行って いる場合がほとんどである.しかし実験の種類によっ ては計測対象となるき裂進展寿命が極めて長い場合や 高温などの苛酷な環境下における観察など多種多様で あり，計測に際しては通常多大の労力と困難さを伴う。 さらに疲労き裂進展下限界值の評価や, 残留応力場中 などのき裂進展シミュレーションのように, き裂長さ に応じて連続的に負荷荷重を制御するといった $K$ 值 制御試験を行う場合にもき裂長さのオンライン計測が 不可欠である.このようにき裂長さ計測の自動化は破 壊力学実験を進める上で重要な課題であり, その手法 確立が強く望まれている.

これまでにも常温下でのき裂進展試験に対しては,
種々のき裂長さの自動計測システムの開発が試みられ てきた. これらのシステムのほとんどはコンプライア ンス法や電位差法などの手法を応用したものである. 前者の方法は負荷時あるいは除荷時に試験対象物のコ ンプライアンスをひずみゲージなどにより計測し，あ らかじめ作成しておいたコンプライアンスと欠陷寸法 との較正関係からき裂長さを算出するものである.こ の手法における最大の問題点はコンプライアンス計測 が接触型になること, 計測対象が単一で直線状のき裂 であること，さらには試験片の種類に応じて較正関係 を準備する必要があることなどであろう。この手法を 高温環境下や腐食環境下試験などへ応用する場合, セ ンサーの耐熱性や耐食性, あるいはき裂の屈曲や分岐 などの問題により，その適用が極めて困難となる。こ れに対して後者の方法は試験片へ通電し，き裂上下面 間の電位差を計測することによりき裂寸法・形状を同 定しようとするものであり, 高温環境下における試験 などへの適用性は良好である. しかし得られた電位差

\footnotetext{
$\dagger$ 原稿受理 平成 2 年 4 月13日 Received Apr. 13, 1990

* 正 会 員 大阪大学基礎工学部 豊中市待兼山町, Faculty of Engineering Science, Osaka University, Machikaneyama-cho, Toyonaka

** 日本電気(株) C\&C システム研究所 川崎市宮前区, C\&C System Research Laboratories, NEC Co., Miyamae-ku, Kawasaki

*** 住友金属工業(株)システムエンジニアリング本部 尼崎市西長洲, System Engineering Business Division, Sumitomo Metal Industries Ltd., Nishinagasu, Amagasaki
} 
と欠陥寸法との較正関係が必要であることやき裂長さ の分解能，システムの簡便性の点ではなお問題があり， 実用段階にまでは至っていないのが現状である.

これら間接的計測法の問題点を解決する非接触・高 精度計測法として, き裂像からの直接計測法すなわ ち移動顕微鏡によるき裂像を肉眼でとらえるかわり に，光学情報を電気信号に変換する CCD (Charge -Coupled Device) カメラによってとらえ画像処理技 術によってき裂長さを同定する計測法が考えられる. これまでにも簡便的な 1 次元画像処理によるき裂長さ 計測はなされてはいるものの, より完全な 2 次元計測 処理を実現するためには処理時間の長さ，画像処理の ための記憶容量の大きさなどに問題が多く, 現実的な 計測法となるまでには到底困難な状態であった，しか しながら近年の画像処理装置の著しい進歩は目を見張 るものがあり，適当な処理手法を応用すれば，き裂長 さの直接計測システムが開発できるレベルに達してき た. そこで本研究では処理時間が数秒以内であるよう なリアルタイムき裂計測を実現するために，ソフト ウェア上の工夫として従来形状認識に用いられてきた テンプレートマッチング手法を改良，き裂先端認識処 理に導入することにより，簡便かつ高速なオンライン き裂長さ計測システムの完成を目指した. 開発したシ ステムはき裂画像の高速画像処理によるき裂先端位置
の同定後，これを追尾するき裂進展試験支援システム である。このシステムを中高温環境下における各種の $K$ 值制御試験に適用し, 負荷荷重制御やき裂進展挙 動の観察について良好な試験結果が得られたので報告 する。

\section{2 き裂進展試験システムの概要}

開発したシステムは，CCD カメラにより取り込ん だき裂画像に対して画像処理を施し，き裂先端を認識 し，これの追跡を行うことによりき裂長さを計測する 画像処理システムである.

Fig. 1 に本システムの基本構成を模式的に示す. 同 図は画像データや信号の流れをも表している. CCD カメラより入力されたき裂画像は画像処理装置におい て画像処理を行い，き裂先端位置を同定し，認識した き裂先端の座標データをホストとなるパーソナルコン ピュータ（PC）に転送する．本報告では大部分が高 温環境下における実験であるので，画像採取には特別 の注意を払い, $\mathrm{CCD}$ カメラ先端の光学系には次の 2 種類の方法をとった. 1 つは望遠顕微鏡タイプのズコ ープであり，もう 1 つは Fig. 2 に示すような $700^{\circ} \mathrm{C}$ 耐熱の石英ファイバースコープを用い，これを高温炉 の中に挿入することにより，き裂画像を得る方法であ る. 前者の場合は倍率が 100 倍, 作動距離が $100 \mathrm{~mm}$ である．また後者の場合には，計測対象物の近傍にま

Test frame

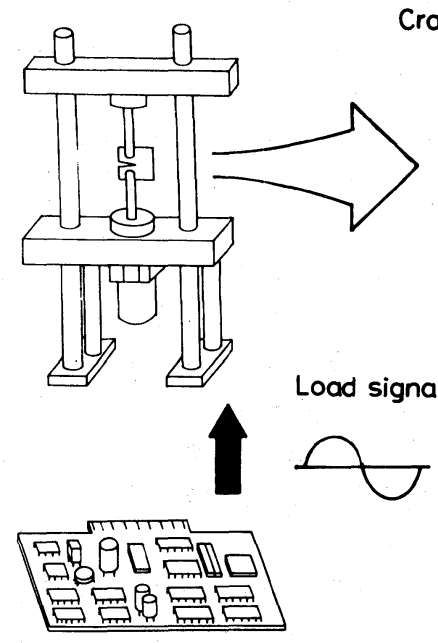

Function generator

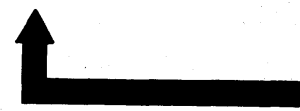

Maximum, minimum load $P_{\text {max }}, P_{\text {min }}$

Cracked sample

Image processor

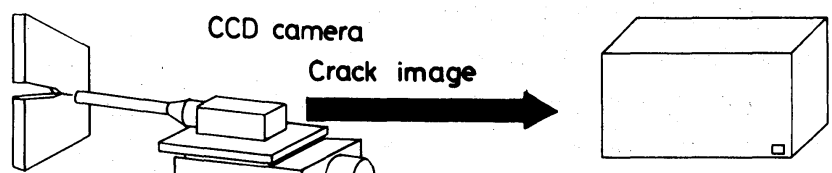

Location of crack tip $X, Y$

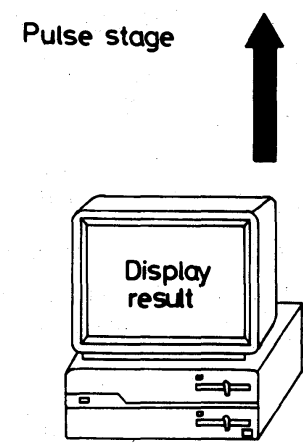

Increment of crack length $\Delta a$

Floppy disk

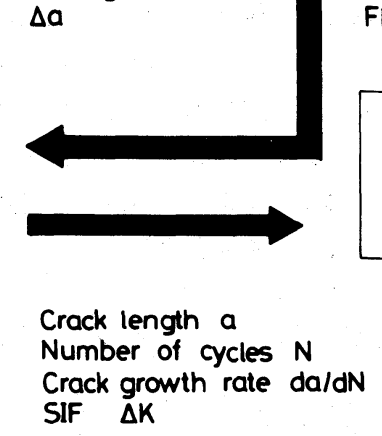

Fig. 1. Schematical diagram of computerized crack growth test system and the stream of signals and image data. 


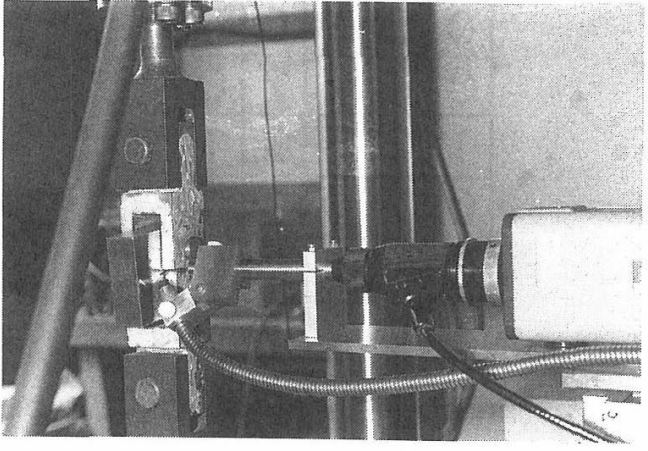

Fig. 2. Details of crystal fiber-optic image guide system

で光学系を接近させることが可能となる，本研究で用 いたファイバースコープの倍率は 50 倍，ファイバー 本数は 3 万本である．PC はき裂先端がカメラ視野中 央に位置するようにパルスステージを駆動する。さら にPC は試験開始時に指定された $K$ 值制御を行うべ く，得られたき裂長さデータから負荷荷重信号のレベ ルを計算し，スロットに内蔵したウェーブジェネレー 夕を制御し，荷重信号をサーボ油圧式疲労試験機に出 力する。 これら一連の制御により, 疲労試験が継続さ れる. システムハードウェアの詳細については既報に 報告しているので省略する。

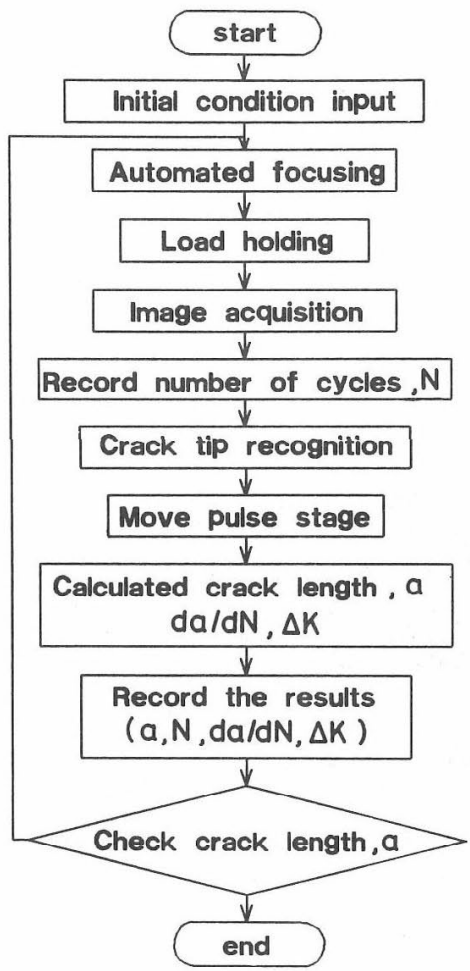

Fig. 3. Flow chart of crack growth test program.
プロダラムは，高速性・汎用性を考え大部分は C 言語で，またより高速な処理を要求される部分につい てはアセンブリ言語で記述している.

本システムを用いて行うき裂進展試験手順をフロー チャートにしてFig. 3 に示す、試験開始にあたりまず 試験片の形状や負荷などの初期条件を入力する。つぎ にき裂画像を取り込むカメラの焦点調整を行う。この 焦点調整は人力画像の濃度分布を調べることにより 行っている、さらにき裂先端認識のためのき裂困像を CCD カメラにより取り込む。このとき疫労試験中す なわち変動荷重が負荷吕れていると, 入力画像にブレ が生じ，明瞭なき裂画像が得られない。そこで画像を 取り込む前に，荷重をいったん平均荷重または最大荷 重で保持し, 静止画像としてから画像取り込みを行っ ている。この時の荷重保持時間は約 1 秒である。この ようにして入力したき裂画像に対し，後述する画像処 理を行い，き裂先端位置を認識し，き裂先端が画面上 の中央に位置するように，パルスステージを制御する ことによりカメラを移動させる。このときのき裂進展 方向（X 軸）のカメラの移動量をき裂長さの增分と みなし，き裂長さを計算する。得られたき裂長さとサ イクル数，入力された初期条件などをもとに $K_{\max }$, $\Delta K, d a / d N$ などの破壊力学パラメータを算出し, 初期条件入力時に指定された $K$ 值制御条件を満足す るような荷重を計算し，荷重調整を行う。これらの測 定結果は，コンピュータのディスプレイ上に表示され ると共にフロッピーディスクに記録される．再び測定 時間になると上述のき裂画像の取り込みをはじめとす る一連の操作が繰り返される。これらの处理はき裂長 さが初期設定したき裂長さに達した場合に終了する。

\section{3 画像処理によるき裂認識手法}

本システムで行うき裂先端認識処理の手順を Fig. 4 に示す．まず $256 \times 256$ 画素の原画像中のき裂の部分 を明確にし，画像に含まれるノイズを除去するために 前処理としてコントラストの强調拉よび平滑化を行う。 ここではまず入力画像の平均濃度が濃度ヒストグラム の中心（濃度值 128 付近）となるように平行移動し， つぎに式 (1)に示すような 3 次関数を用いて濃度変換 を行う

$$
f(x)=-x^{2}(x-3 \times 255 / 2) \times\left(2 / 255^{2}\right)
$$

一方, 平滑化は一種のノイズフィル夕処理であり, 注目点の濃度值をその周囲の点の濃度值の平均值とな るようにしている。この処理を施すと画像のコントラ ストが弱くなるので，Fig. 5 に示すような $5 \times 5$ のマ スクによる重みつき平均による平滑化を行っている.

Fig. 6 (a)のき裂原画像に対してこのような前処理を 行った後の画像がFig. 6 (b)である。この画像に対し て垂直方向の濃度分布を計算する．得られた結果を 


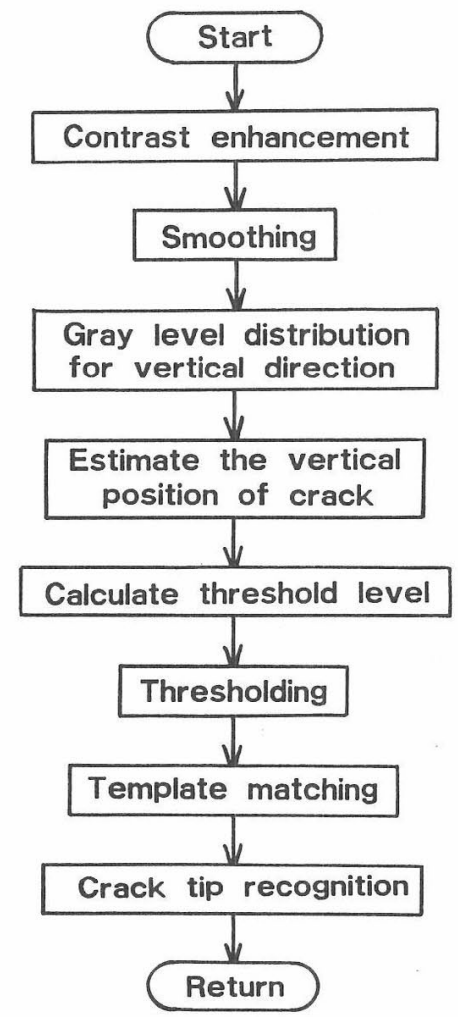

Fig. 4. Details of crack tip recognition algorithm.

Fig. 6 (c) に示す。この垂直方向濃度分布においてき裂 の存在する部分の平均濃度は周囲のそれと比較して高 くなる，そこで，最も高い平均濃度の位置をき裂先端 が存在する垂直方向位置すなわち $\mathrm{Y}$ 座標であると推 定する.

つぎに，き裂画像に対して 2 值化を行い，き裂像の 幾何的特徵を抽出する. 2 值化処理においてはしきい 值の選択が最も重要な要因となる。ここではき裂画像 の濃度ヒストグラムから適切なしきい值を推定してい

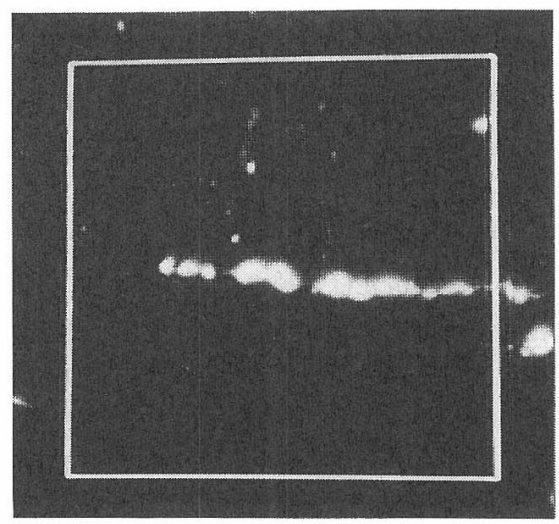

(a) Original crack image

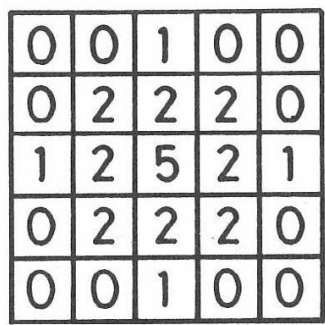

Fig. 5 . $5 \times 5$ filter for smoothing.

る。き裂画像においてき裂の部分は試験片表面におけ るバックグラウンドの濃度よりも高い濃度值を有する が，実際のき裂画像にはキズなどの原因によりき裂以 外の部分で濃度值の高い画素が現れ, き裂画像全体の 濃度ヒストグラムからしきい值を決定することが困難 となる。そこで先に推定したき裂先端 $\mathrm{Y}$ 座標を中心 にき裂先端検索対象領域を定め, この領域に対してヒ ストグラムを調べ，2值化レベルを決定している。

最後に計算された 2 值化レベルを用いて 2 值化を行 い, 得られた画像につき，き裂先端の X 座標の推定 を行う. 2 值化画像中のき裂はほとんどの場合，分断 ・屈曲を伴っている。 そこでこのようなき裂画像に対 して正確なき裂先端位置の同定が行えるようにするた め，以下に述べるようなテンプレートを用いている。

まず，2 值化の際に設定した検索領域内において，

Fig. 6 (d) に示すような $40 \times 3$ 画素のテンプレートを考 える。き裂が右から左へ進展すると,このテンプレー 卜を用いて検索領域の左上方からテンプレートを当て はめ，テンプレート内で X 軸方向に対して ON（濃 度 255）となっている画素の数を数え，それがある基 準（ここでは 40 画素中 32 画素以上）を越える場合に は，その部分がき裂の一部であると考え，Fig. $6(\mathrm{e}) に$ 示すようにテンプレートの左端をき裂先端と判断する。 これらき裂先端認識に関する処理時間は約 5 秒である.

き裂先端位置が決定されると, き裂先端位置が処理

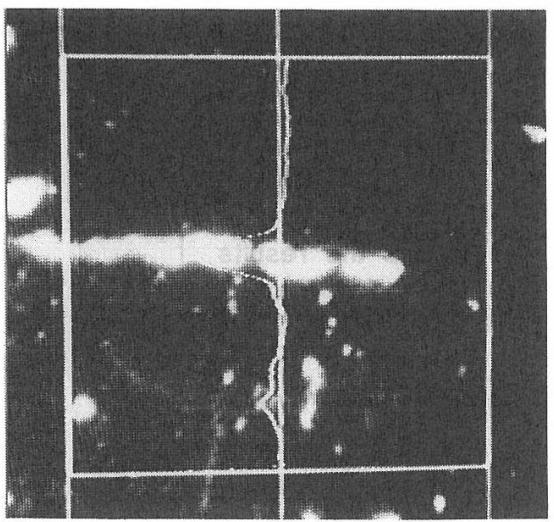

(b) Pre-processed image of Fig. 6(a).

Fig. 6(A). Example of crack image at different processing stage. 

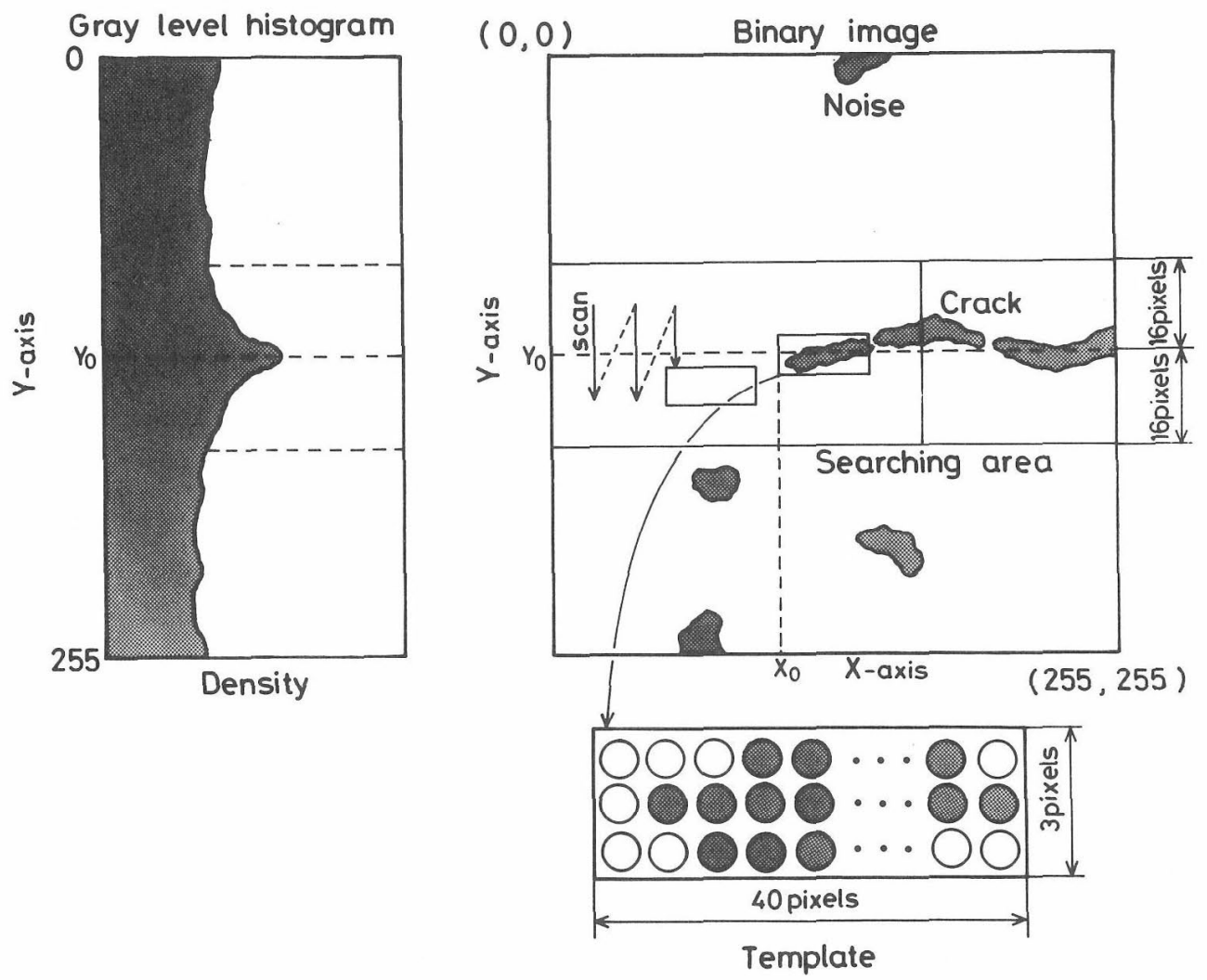

(c) Gray level distribution.

(d) Template scanning technique for crack tip recognition.

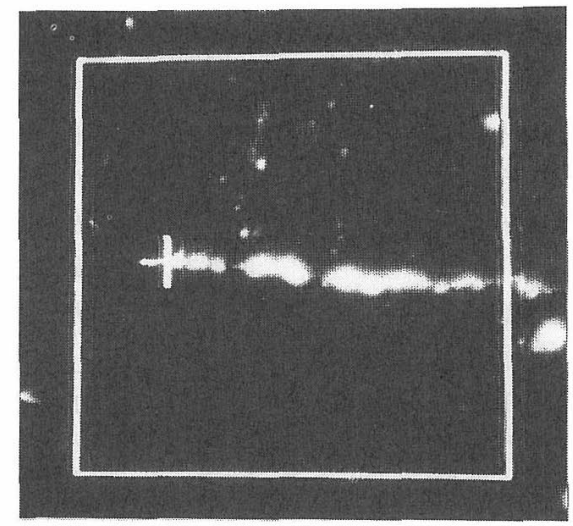

(e) Detected crack tip location.

Fig. 6(B). Example of crack image at different processing stage.

画面上に設定した固定座標点と一致するようにパルス ステージを移動する。このときのステージの移動量が き裂長さの増分に対応し，き裂進展量が算出される。

\section{4 各種 $\Delta \boldsymbol{K}$ 制御き裂進展試験結果}

開発したき裂進展試験システムを用いて各種の $K$ 值制御き裂進展試験を行った. 試験はすべて CT 試 験片を用いて行った。以下にその結果を示す。

(1) 常温下における疲労き裂進展試験

まず本システムを用いた $\Delta K$ 制御試験の一例とし
て常温下において $\Delta K$ 一定試験を行った. 試験片は SM50A 鋼 CT 試験片であり， $650^{\circ} \mathrm{C} 30$ 分保持後炉冷のひずみ取り焼なましを施したものを用 いた.Fig.7(a) は縦軸にき裂長さ, 横軸に繰返し数を とってまとめたものである. 荷重繰返し数の増加にと もない, き裂長さもほぼ一定の勾配で直線的に増加し ていることがわかる. Fig. 7 (b) は Fig. 7 (a)のデー夕 より計算したき裂進展速度を縦軸にとり再整理したも のである。図からわかるようにき裂長さによらずき裂 


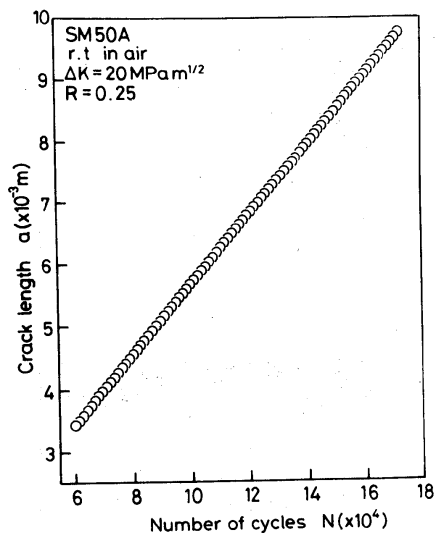

(a) Crack growth rate as a function of crack length.

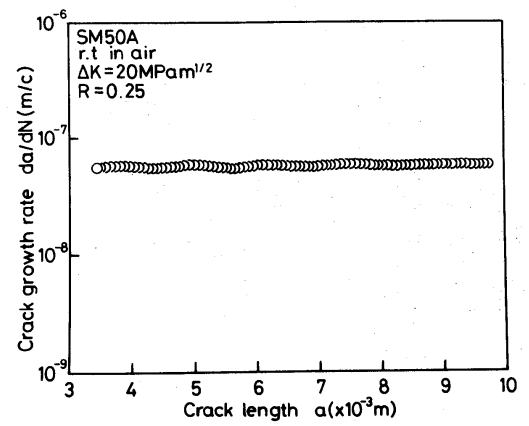

(b) Crack growth rate plotted against stress intensity factor.

Fig. 7. Result obtained from a $K$-constant test at room temperature.

進展速度が一定であり，き裂先端認識結果に基づき計 算されたき裂長さの計測結果ならびにその值より算出 された負荷荷重などがきわめて正確であることがわか る.

\section{（2）中高温下における疲労き裂進展試験}

本システムの大きな目的の一つに高温環境下試験へ の応用がある。まず本システムの高温環境下における き裂進展試験への応用として, $300^{\circ} \mathrm{C}$ の試験温度条件 下において数種類の $K$ 值制御試験を行った。用いた 材料は SM41A 鋼であり, 試験片に加工した後 $650^{\circ} \mathrm{C}$ 30 分保持後炉冷の熱処理を施した.

Fig. 8 に各試験に扔ける $K$ 值変化を示す. 縦軸に は実験開始時の初期 $K$ 值を基準とした無次元応力拡 大係数幅 $\Delta K / \Delta K_{0}$ を, 横軸には初期き裂長さからの 長さ増分 $\Delta a\left(=a-a_{0}\right)$ をとって整理したものである. 図には常温下試験における $K$ 值変化をも併せて示し てある．図より試験温度によらず，また $K$ 值制御の 方法によらずほぼ連続的に滑らかな $K$ 值制御が行わ れていることがわかる.

このような $K$ 值制御下におけるき裂進展試験を 行った結果, 得られたき裂進展速度 $d a / d N$ と $\Delta K$

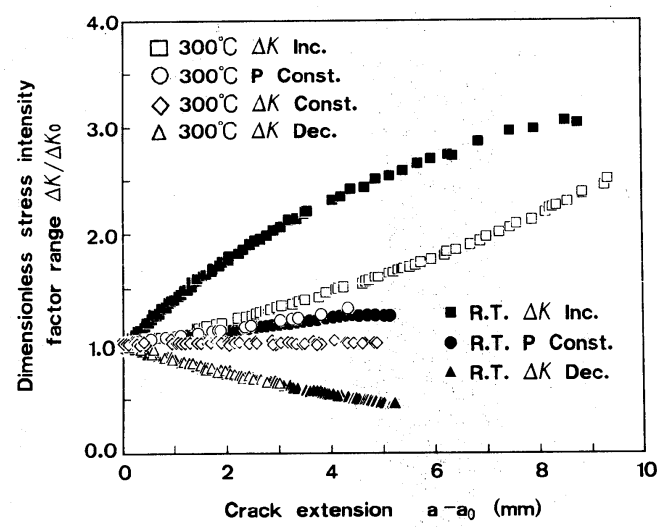

Fig. 8. Stress intensity factor range as a function of crack length in several $K$-controlled tests at elevated temperature.

の関係を Fig. 9 に示す．図中には比較のため既報にお いて得られた中高温下におけるデー夕を実線にて併せ て示した．各試験条件下におけるデー夕はそれぞれの 温度において 1 本のデータバンド内に整理され，また $K$ 值制御の方法による相違も認められない.ここで 示した以外にも種々の $K$ 值制御方法により試験を 行っているが, これらから得られたデー夕もすべて上 述のデータバンド内に整理され, 試験方法がき裂進展 挙動に及ぼす影響は極めて小さいことがわかる.

(3) 高温下 $\Delta K$ 值漸減試験結果

高温下におけるき裂進展試験へのもう一つの応用例 として $\Delta K$ 漸減試験を行った. $\Delta K$ 漸減試験は疲労 き裂の進展下限界挙動を調べる際に必要となる.ここ では荷重漸減の割合を表す漸減率の影響を調べるため に行った種々の漸減率における下限界試験について報 告する. 漸減率 $C$ の定義は次式のとおりである.

$$
\Delta K=\Delta K_{0} \exp \left[\mathrm{C}\left(a-a_{0}\right)\right]
$$

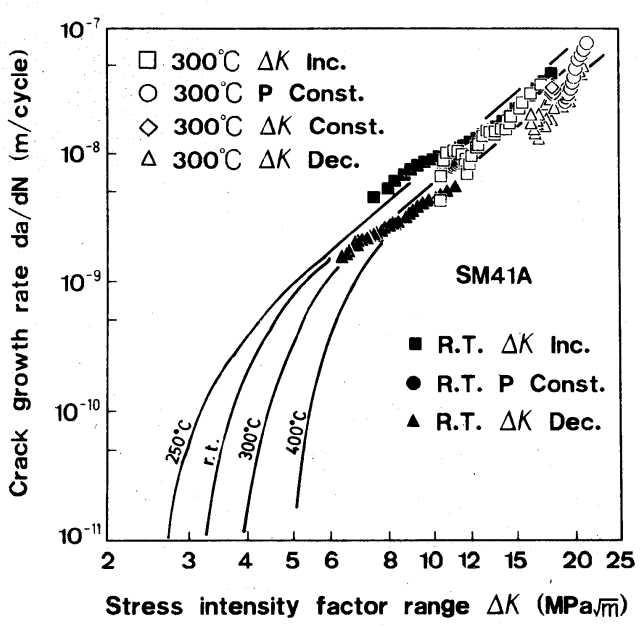

Fig. 9. Crack growth rate plotted against stress intensity factor range at elevated temperature. 


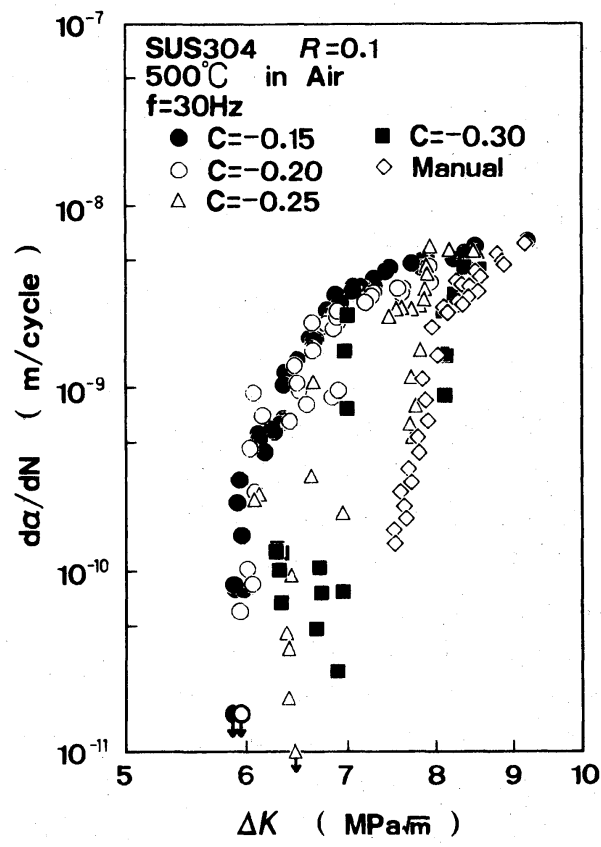

Fig. 10. Crack growth rate plotted as a function of stress intensity factor range at elevated temperature.

ここで $\Delta K_{0}$ は初期応力拡大係数幅， $a_{0}$ は初期き裂長 さである. 試験は $500^{\circ} \mathrm{C}$ の高温大気中, 応力比 $R$ $=0.1$ で行った. 用いた材料は SUS304 鋼であり, $1050^{\circ} \mathrm{C} 30$ 分の溶体化処理を施したものである. 漸減 率 $C$ は $-0.15,-0.20,-0.25,-0.30$ の 4 種類を 選んだ.

得られたき裂進展速度を応力拡大係数幅で整理した 結果が Fig. 10 である. $C=-0.30$ といった漸減率 $C$ の絶対値の大きい実験における結果は進展速度のばら つきが大きいが，漸減率 $C$ の絶対值が低下するにつ れてこのばらつきも小さくなり，進展速度が滑らかに 変化することがわかる. また得られた進展下限界值 $\Delta K_{\text {th }}$ も漸減率の絶対值の低下にともない小さい值と なっている. しかし $\Delta K_{\mathrm{th}}$ 值の $C$ 依存はその進展速 度への影響に比べると比較的小さなものとなっている. 本実験で対象としたような漸減率 $C$ の範囲における 常温下・下限界值はあまり $C$ に依存しないことが報 告されているが, 高温下における $\Delta K_{\mathrm{th}}$ 值に対しても 上述のごとく比較的 $C$ に不敏感であるようである.

$$
5 \text { 結論 }
$$

画像処理を援用したリアルタイムき裂先端認識処理 手法を開発し，これを用いてき裂先端追尾によるき裂 進展試験システムを構築した。

開発したシステムを常温から中高温下にいたる試験
温度域における $K$ 值漸減・漸增・一定荷重振幅疲労 き裂進展試験に応用した，得られた結果は連続的であ り，計測されたき裂長さに基づく $K$ 值制御がきわめ て高精度に行うことが可能であった. さらに本システ 厶を用いて高温下におけるき裂進展下限界值に及ぼす $K$ 值漸減率の影響を SUS304 鋼について調べた. 漸 減定数 $C=-0.25$ 程度までは得られる下限界值に及 ぼす漸減定数の影響は小さいことが明らかとなった.

本研究は倉田奨励金の補助を得た。また装置使用に 関して小松商事(株)萩下志朗社長から便宜を受けた。実 験遂行にあたっては稲村文秀君（大阪大学大学院）の 協力を得た. 記して謝意を表する.

(平成元年 9 月 28 日 第 5 回破壊力学シンポジウムにて講演)

\section{参 考 文 献}

1 ) R. S. Vecchio, D. A. Jablonski and B. H. Lee, ASTM STP 877, 44 (1985).

2) Y. Kondo and T. Endo, ASTM STP 877, 118 (1985).

3 ) R. F. Smith and P. Doig, Engg. Fract. Mechs., 23, 965 (1986).

4 ）菊川 真, 城野政弘, 田中健一, 近藤良之, 田畑文夫, 村田洋一, 材料, 29, 1240 (1980).

5 ) 松岡三郎, 西島 敏, 大坪昌一, 日本機械学会論文集, A-48, 1505 (1982).

6 ) 矢川元基, 橋爪秀利, 副田俊彦, 黒沢正蔵, 日本機械学 会論文集，A-51，254（1985）.

7 ) W. R. Catlin, D. C. Lord, T. A. Prater and L. F. Coffin, ASTM STP 877, 67 (1985).

8 ) D. A. Topp and W. D. Dover, ASTM STP 877, 87 (1985).

9) P. M. Sooley and D. W. Hoeppner, ASTM STP877, 101 (1985).

10）上田澄広，金丸孝夫，システムと制御，27，130（1983）。

11）小倉敬二, 三好良夫, 西川 出, 藤原弘次, 森川 自, 日本材料学会第24回 X 線材料強度に関するシンポジウ 厶講演論文集, p. 139 (1987).

12）小倉敬二, 三好良夫, 西川 出, 藤原弘次, 森川 自, 日本機械学会講演論文集, No. 870-13，37 (1987).

13) I. Nishikawa, Y. Miyoshi and K. Ogura, Proc. VI Int. Congr. on Exp. Mechs., p. 89 (1989).

14）小倉敬二, 三好良夫, 西川 出; 藤原弘次, 森川 自, 第11回 NCP シンポジウム論文集, p. 19 (1988).

15）小倉敬二, 三好良夫, 西川 出, 藤原弘次, 森川 自, 日本機械学会講演論文集, No. 884-1, 127 (1988).

16) A. Saxena, S. J. Hudak, Jr., J. K. Donald and D. W. Schmidt, J. of Testing and Evaluation, 6, 3, 167 (1976).

17) A. Ohta and E. Sasaki, Engg. Fract. Mechs, 9, 655 (1977). 